\title{
Efficacy of Citicolline in Treatment of Amblyopia as an Adjunct to Patching
}

\author{
Anurag Narula ${ }^{1}$, Rajiv Kumar², Shilpa Singh ${ }^{3 *}$ and Manish Yadav ${ }^{1}$ \\ ${ }^{1,2}$ VMMC and Safdarjung Hospital, India \\ ${ }^{3}$ Visitech Eye Centre, India
}

Submission: July 30, 2018; Published: September 21, 2018

*Corresponding author: Shilpa Singh, D-II/368 Pandara Road New Delhi-3, Tel: 8447547465; Email: drshilpasingh@gmail.com

Abstract

Aim: To study the effectiveness of the addition of citicoline to patching in the treatment of amblyopia in the age group of 4-12 years.

Materials and methods: A randomized controlled trial, which included 30 patients who were randomly divided into two groups. Both the groups received patching therapy for 6 months or till plateau was reached. Then in phase 2, group I received citicoline plus patching and group II continued to receive only patching.

Outcome measures: Outcome was measured by the visual acuity using snellens chart every month till 6 months when citicolline was added to one group and the visual acuity was recorded 2 monthly.

Results: No significant difference was found in the mean visual acuities in these two groups in first 6 months or till plateau was reached. After starting citicolline in one group for the initial two months, there was no significant difference in the visual acuities in these two groups, at the respective intervals. However, four months onward, up to 12 months, there was a significant difference in the visual acuities in these groups. The result was the same in younger patients (< eight years of age) as well as in older patients (> eight years of age). After starting citicolline the improvement in group I was significantly more than that in group II, at two months and onward, at the respective intervals.

Conclusion: The improvement in visual acuity with citicoline plus patching was significantly more than that with patching alone.

\section{Introduction}

Amblyopia is the most common cause of monocular visual impairment in children, young, and middle-aged adults [1]. There is a consensus that amblyopia can be effectively treated in young children [2-4]. Although there has been, in the past, a general belief that treatment beyond a certain age is ineffective, it has been conclusively proved that 'age' is no bar, for the success of the treatment of anisometropic amblyopia [5]. Some believe that a treatment response is unlikely after the age of six or seven years, while others consider the age of nine or ten years to be the upper age limit for successful treatment [6-10]. However, there are many studies involving older children and adults with amblyopia, responding to treatment with patching [11-24].

Occlusion therapy with patching of the sound eye has been the conventional treatment. However, there are many studies stating the effectiveness of some pharmacological agents in the treatment of amblyopia - citicoline is one of them $[25,26]$.

Citicoline (cytidine-5-diphosphocholine) activates the biosynthesis of structural phospholipids in the neuronal cell membranes, which results in increased levels of neurotransmitters, and thus, has neuroprotective effects [27]. It has also been shown to improve the learning and memory performance. There are few animal studies that have reported the enhancement of dopaminergic neurotransmission in the brain with citicoline (exogenous cytidine- $5^{\prime}$-diphosphocholine). A study aimed at determining whether citicoline $(50 \mathrm{mg} /$ kg., twice daily) could influence retinal catecholamine levels in adult male Albino rabbits, has reported that, compared to vehicle-treated controls, citicoline-treated animals displayed a significantly higher retinal dopamine concentration and a tendency toward an increase in adrenaline concentration, while the noradrenaline concentration remained unchanged [28].

\section{Materials and Methods}

a) Patients in the Age Group of 4 To 12

b) Not Having any other Ophthalmic Morbidity

c) Not Having Any Allergy to Citicolline

The following tests were conducted:

A. Complete refractive status of both eyes

B. Cover test/uncover test for the amount of squint and type of squint, added vertical or oblique deviation 

C. Alternate cover test
D. Extraocular movements
E. Prism cover test
F. Forced duction test as per the case, local or general anesthesia

G. Direct ophthalmocopy for eccentric fixation in strabismic amblyopia

H. Observation of result on initial patching therapy in strabismic cases.

\section{Color vision testing.}

Following this, the patching therapy was started in both groups. The patients were followed at one month intervals and visual acuity was recorded. If there was no improvement in the visual acuity for three consecutive followups, then a plateau was considered. It was approximately corresponding to the maximum correction that could be achieved with patching. Once a plateau was achieved, second part of study was started.

Group I received citicoline in addition to continued patching. The doses of citicoline were $250 \mathrm{mg}$ BD (for patients below five years) and $500 \mathrm{mg}$ BD (for patients above five years). Group II continued to receive only patching. Dosage was continued for 45 days then gap of 15 days and then 2 more such cycles. Visual acuity was calculated at 2 monthly interval.

\section{Results}

No significant difference was found in the mean visual acuities in these two groups in first 6 months or till plateau was reached. After starting citicolline in one group for the initial two months, there was no significant difference in the visual acuities in these two groups, at the respective intervals. However, four months onward, up to 12 months, there was a significant difference in the visual acuities in these groups. The result was the same in younger patients (< eight years of age) as well as in older patients ( $>$ eight years of age). After starting citicolline the improvement in group I was significantly more than that in group II, at two months and onward, at the respective intervals.

\section{Discussion}

Drawbacks of study include not being a double blind trial and having just 30 patients. The present multicentric study was carried out to find out the effectiveness of the addition of citicoline to the conventional patching therapy for the treatment of amblyopia. This study has suggested that addition of citicoline, even after maximum improvement with conventional patching was achieved, can further improve the visual acuity.

Citicoline primarily acts by increasing the synthesis of phosphatidylcholine, the primary neuronal membrane phospholipid, thus enhancing the production of acetylcholine. Oral citicoline administration increases the plasma levels of choline and cytidine, the building blocks used to restore neuronal membrane integrity [32]. It is also postulated that citicoline facilitates the preservation of sphingomyelin, which promotes signal transduction in nerve cells [33].

Citicoline may significantly impact the brain-remodeling activity. A study in rats has shown that citicoline treatment significantly increases the length and branch points of the dendrites, increasing the overall surface area occupied by neurons, which leads to an increased efficiency of sensory information processing. This mechanism of activity may potentially account for a significant portion of citicoline's neurorestorative functions [34].

\section{References}

1. Attebo K, Mitchell P, Cumming R, Smith W, Jolly N, et al. (1998) Prevalence and causes of amblyopia in an adult population. Ophthalmology 105(1): 154-159.

2. Pediatric Eye Disease Investigator Group (2002) A randomized trial of atropine vs patching for treatment of moderate amblyopia in children. Arch Ophthalmol 120(3): 268-278.

3. Neumann E, Friedman Z, Abel-Peleg B (1987) Prevention of strabismic amblyopia of early onset with special reference to the optimal age for screening. J Pediatr Ophthalmol Strabismus 24(3): 106-110.

4. Scott WE, Dickey CF (1988) Stability of visual acuity in amblyopic patients after visual maturity. Graefes Arch Clin Exp Ophthalmol 226(2): 154-157.

5. Patwardhan NA (2007) Is age relevant for the success of treatment of anisometropic amblyopia? Indian J Ophthalmol 55(6): 469-470.

6. Quah BL, Tay MT, Chew SJ, Lee LK (1991) A study of amblyopia in 18-19 year old males. Singapore Med J 32(3): 126-129.

7. Epelbaum M, Milleret C, Buisseret P, Dufier JL (1993) The sensitive period for strabismic amblyopia in humans. Ophthalmology 100(3): 323-327.

8. Flynn JT, Schiffman J, Feuer W, Corona A (1998) The therapy of amblyopia: An analysis of the results of amblyopia therapy utilizing the pooled data of published studies. Trans Am Ophthalmol Soc 96: 431-453.

9. Simons K, Preslan M (1999) Natural history of amblyopia untreated owing to lack of compliance. Br J Ophthalmol 83(5): 582-587.

10. Assaf AA (1982) The sensitive period: transfer of fixation after occlusion for strabismic amblyopia. Br J Ophthalmol 66(1): 64-70.

11. Kupfer C (1957) Treatment of amblyopia exanopsia in adults; a preliminary report of seven cases. Am J Ophthalmol 43(6): 918-922.

12. Brown MH, Edelman PM (1976) Conventional occlusion in the older amblyope. Am Orthopt J 26: 34-36.

13. Sen DK (1984) Results of treatment in amblyopia associated with unilateral high myopia without strabismus. Br J Ophthalmol 68(9): 681-685.

14. Oliver M, Neumann E, Chaimovitch Y, Gotesman N, Shimshoni M (1986) Compliance and results of treatment for amblyopia in children more than 8 years old. Am J Ophthalmol 102(3): 340-345.

15. Wick B, Wingard M, Cotter S, Scheiman M (1992) Anisometropic amblyopia: Is the patient ever too old to treat? Optom Vis Sci 69(11): 866-878.

16. Noda S, Hayasaka S, Setogawa T (1993) Occlusion therapy of Japanese children with anisometropic amblyopia without strabismus. Ann Ophthalmol 25(4): 145-147.

17. Tsubota K, Yamada M (1994) Treatment of amblyopia by extendedwear occlusion soft contact lenses. Ophthalmologica 208(4): 214-215. 
18. Woodruff G, Hiscox F, Thompson JR, Smith LK (1994) Factors affecting the outcome of children treated for amblyopia. Eye (Lond) 8(Pt 6): 627-631.

19. Simmers AJ, Gray LS (1999) Improvement of visual function in an adult amblyope. Optom Vis Sci 76(2): 82-87.

20. Mintz-Hittner HA, Fernandez KM (2000) Successful amblyopia therapy initiated after age 7 years: Compliance cures. Arch Ophthalmol 118(11): 1535-1531.

21. Pediatric Eye Disease Investigator Group (2004) A prospective, pilot study of treatment of amblyopia in children 10 to $<18$ years old. Am J Ophthalmol 137(3): 581-583.

22. Mohan K, Saroha V, Sharma A (2004) Successful occlusion therapy for amblyopia in 11- to 15-year-old children. J Pediatr Ophthalmol Strabismus 41(2): 89-95.

23. Park KH, Hwang JM, Ahn JK (2004) Efficacy of amblyopia therapy initiated after 9 years of age. Eye (Lond) 18(6): 571-574.

24. Magoon EH, Garuda S (2000) Visual acuity plasticity in amblyopes between age 10 and 14. In: Scott A (Ed.), Proceedings of the Jampolsky Festschrift. Smith-Kettlewell Eye Research Institute. San Francisco, Calif, USA.

25. Campos EC, Frenisa M (2006) Medical treatment of amblyopia: Present state and perspectives. Strabismus 14(2): 71-73.
26. Chatzistefanou KI, Mills MD (2000) The role of drug treatment in children with strabismus and amblyopia. Paediatr Drugs 2(2): 91-100.

27. Secades JJ, Frontera G (1995) CDP-choline: Pharmacological and clinical review. Methods Find Exp Clin Pharmacol 17 Suppl B: S1-S54.

28. Rejdak R, Toczoowski J, Solski J, Duma D, Grieb P (2002) Citicoline treatment increases retinal dopamine content in rabbits. Ophthalmic Res 34(3): 146-149.

29. Campos EC, Schiavi C, Benedetti P, Bolzani R, Porciatti V (1995) Effect of citicoline on visual acuity in amblyopia: Preliminary results. Graefe's Arch Clin Exp Ophthalmol 233(5): 307-312.

30. Fresina M, Dickmann A, Salerni A, De Gregorio F, Campos EC (2008) Effect of oral CDP-choline on visual function in young amblyopic patients. Graefes Arch Clin Exp Ophthalmol 246(1): 143-150.

31. Stewart CE, Moseley MJ, Fielder AR (2003) Defining and measuring treatment outcome in unilateral amblyopia. Br J Ophthalmol 87: 12291231.

32. D'Orlando KJ, Sandage BW (1995) Citicoline (CDP-choline): Mechanisms of action and effects in ischemic brain injury. Neurol Res 17(4): 281-284.

\section{Your next submission with Juniper Publishers will reach you the below assets}

- Quality Editorial service

- Swift Peer Review

- Reprints availability

- E-prints Service

- Manuscript Podcast for convenient understanding

- Global attainment for your research

- Manuscript accessibility in different formats

( Pdf, E-pub, Full Text, Audio)

- Unceasing customer service

Track the below URL for one-step submission https://juniperpublishers.com/online-submission.php 